\title{
Localization of Actin mRNA during the Establishment of Cell Polarity and Early Cell Divisions in Fucus Embryos
}

\author{
François-Yves Bouget, Suzanne Gerttula, Sidney L. Shaw, and Ralph S. Quatrano' \\ Department of Biology, University of North Carolina, Chapel Hill, North Carolina 27599-3280
}

\begin{abstract}
Localization of mRNA is a well-described mechanism to account for the asymmetric distribution of proteins in polarized somatic cells and embryos of animals. In zygotes of the brown alga Fucus, F-actin is localized at the site of polar growth and accumulates at the cell plates of the first two divisions of the embryo. We used a nonradioactive, whole-mount in situ hybridization protocol to show the pattern of actin mANA localization. Until the first cell division, the pattern of actin mRNA localization is identical to that of total poly(A) ${ }^{+}$RNA, that is, a symmetrical distribution in the zygote followed by an actin-dependent accumulation at the thallus pole at the time of polar axis fixation. At the end of the first division, actin mRNA specifically is redistributed from the thallus pole to the cell plates of the first two divisions in the rhizoid. This specific pattern of localization in the zygote and embryo involves the redistribution of previously synthesized actin mRNA. The initial asymmetry of actin mRNA at the thallus pole of the zygote requires polar axis fixation and microfilaments but not microtubules, cell division, or polar growth. However, redistribution of actin mRNA from the thallus pole to the first cell plate is insensitive to cytoskeletal inhibitors but is dependent on cell plate formation. The F-actin that accumulates at the rhizoid tip is not accompanied by the localization of actin mRNA. However, maintenance of an accumulation of actin protein at the cell plates of the rhizoid could be explained, at least partially, by a mechanism involving localization of actin mRNA at these sites. The pattern and requirements for actin mRNA localization in the Fucus embryo may be relevant to polarization of the embryo and asymmetric cell divisions in higher plants as well as in other tip-growing plant cells.
\end{abstract}

\section{INTRODUCTION}

The formation of a polarized cell depends on the asymmetric distribution and localized activity of proteins (Horvitz and Herskowitz, 1992). Although much is known about vesicular trafficking that targets membrane-associated proteins to cellular compartments, the mechanism(s) responsible for the localization of soluble cytoplasmic proteins is less well understood. Numerous studies indicate that requirements for localized protein accumulation can be achieved by protein redistribution, translation followed by protein targeting, or transport and stabilization of mRNA for local translation (see St. Johnston, 1995).

Although the intracellular localization of specific mRNAs has been reported in somatic cells of animals (Wilhelm and Vale, 1993), most of the earliest and best known examples are in oocytes and embryos. Several mRNAs for regulatory proteins exhibit specific patterns of spatial distribution in Drosophila and Xenopus oocytes and embryos (St. Johnston and NüssleinVolhard, 1992; Thomsen and Melton, 1993). When translated, these localized mRNAs create gradients of protein that direct cell differentiation, fate determination, and pattern formation. For example, in Drosophila oocytes the transport of oskar

\footnotetext{
1 To whom correspondence should be addressed.
}

mRNA to the posterior pole is important to define the anteroposterior axis of polarity. The formation of this axis is disrupted in mutants in which oskar mRNA is not localized or when oskar mRNA is artificially misdirected in the oocyte (Ephrussi and Lehman, 1992).

Specific intracellular localizations of mRNA encoding cytoskeletal proteins, that is, actin, tubulin, and intermediate filaments, have also been described in oocytes and embryos (Jeffery et al., 1983; Cox et al., 1986; Burn et al., 1989; Jeffery, 1989; Beach and Jeffery, 1990; Tobin et al., 1990) as well as in differentiated somatic cells of animals (Lawrence and Singer, 1986; Cheng and Bjernes, 1989; Hill and Gunning, 1993). Several lines of evidence suggest that mRNA localization accounts for the polar accumulation of cytoskeletal proteins (see Wilhem and Vale, 1993). For example, $\beta$-actin transcripts localize to the leading lamellae of chicken embryonic fibroblasts. Microinjection of oligonucleotides directed against the mRNA localization signals disrupts not only $\beta$-actin mRNA localization but also the spatial segregation of its cognate protein (although the levels of both protein and mRNA are unaffected). The effect on the cells is dramatic: they lose their polarity and become symmetric (Kislauskis et al., 1994). Hence, it appears that correct mRNA localization within a single cell may also be crucial for generating or maintaining cell polarity. 
Our long-term interest is to understand the mechanisms responsible for establishing polarity in plant embryos (see Goodner and Quatrano, 1993; Kropf, 1994; Fowler and Quatrano, 1995). The fertilized Fucus egg is initially apolar, but an external gradient, such as unilateral light, can orient an axis of polarity that becomes irreversibly fixed at $\sim 10 \mathrm{hr}$ after fertilization (AF) (Quatrano, 1973). At the time of polar axis fixation, F-actin accumulates at the site of future polar growth (Brawley and Robinson, 1985; Kropf et al., 1989a). This localization of F-actin at the presumptive site of polar growth is the first stable asymmetry observed in the zygote. The accumulation of F-actin is correlated temporally with the fixation of the polar axis and associated spatially with the site to which vesicle transport is directed to support rhizoid outgrowth (Brawley and Quatrano, 1979a).

The importance of the correct localization of F-actin in zygotes is demonstrated by experiments in which actin microfilaments are disrupted with cytochalasin $B(C B)$. CB prevents not only the ability of the zygote to form an axis of polarity in a unilateral light gradient, but also the fixation and stabilization of the polar axis, vesicle targeting, and the ensuing asymmetrical first division (Quatrano, 1973). The localized network of actin microfilaments remains at the tip of the elongating rhizoid through several cell divisions of the embryo, similar to other tip-growing systems (Heath, 1990). Hence, the F-actin localized at the fixed site of polar growth may play a major role in establishing and stabilizing the polar axis of the Fucus zygote, which then serves as the axis for the first oriented asymmetric cell division of the zygote and the polarity of the embryo.

In addition to the localization of F-actin at the site of polar growth of the embryo, a recent report describes the existence of "actin collars" in the embryo-an accumulation of F-actin at the cell plates of the first two divisions in the rhizoid (Kropf et al., 1992). These first two divisions, which produce the thallus cell and two rhizoid cells, are unique in the embryo because they are asymmetric and include nuclear reorientation (Allen and Kropf, 1992). The process of an oriented nuclear rotation ensures a division plane that is perpendicular to the long axis of the rhizoid filament. The possible role of the F-actin collars in these divisions or in filament growth is not known.

We are interested in determining whether the distribution of actin mANA could spatially and temporally account for the accumulation pattern of F-actin in the Fucus zygote and early embryo and, if so, in elucidating the requirements for actin mRNA localization. Recently, we developed a nonradioactive, whole-mount in situ hybridization protocol for Fucus zygotes and embryos (Bouget et al., 1995a). Using this protocol, we have shown that stored and newly synthesized poly $(A)^{+}$RNA becomes localized in an actin-dependent manner at the thallus pole of the zygote when the polar axis is established (Bouget et al., 1995b). In this study, we determined the pattern of actin mRNA distribution, using the same technique, and we show that the pattern of actin mRNA localization in Fucus zygotes can be described in two stages - before and after the first cell division.
Until the first cell division, the pattern of actin mRNA localization is identical to that of total poly $(A)^{+}$RNA, that is, a symmetrical distribution in the zygote followed at 8 to $10 \mathrm{hr}$ $\mathrm{AF}$ by an actin-dependent accumulation at the thallus pole. No specific segregation of actin mRNA was observed at the rhizoid pole where F-actin begins to accumulate at the tip of the emerging rhizoid. At the end of the first division, unlike most mRNAs, actin mRNA is specifically redistributed from the thallus pole to the cell plates of the first two divisions in the rhizoid; this is the site of the F-actin accumulation in the actin collars of the embryo.

We show that establishment of actin mRNA asymmetry in the zygote requires polar axis fixation and microfilaments but is independent of polar growth of the rhizoid and whether cell division occurs in a symmetric or asymmetric manner. Furthermore, redistribution of actin mRNA from the thallus pole to the site of $\mathrm{F}$-actin accumulation at the first cell plate involves neither intact microfilaments nor microtubules but requires cell plate formation. We hypothesized that the F-actin that localizes at the tip of the rhizoid cell is redistributed at the time of polar axis fixation by a mechanism that does not involve localization of actin mRNA. However, maintenance of an accumulation of actin protein at the cell plates of the rhizoid could be explained, at least partially, by a mechanism involving localization of actin mRNA at these sites.

\section{RESULTS}

To localize actin mRNA in zygotes and embryos, we used a digoxigenin (DIG)-based, whole-mount in situ hybridization protocol developed for Fucus (Bouget et al., 1995a). With this protocol, we determined the spatial and temporal distribution pattern of actin mRNA, using actin cDNA (A7) from Fucus as a probe (Goodner et al., 1995). The distribution of the nuclearencoded fucoxanthin chlorophyll protein A $\left(F_{C} p A\right)$ mRNA from the brown alga Macrocystis (Apt et al., 1995) and poly $(A)^{+}$ RNA was also monitored to assess the specificity of actin mRNA localization patterns. Using the same Fucus actin probe, we found that the steady state levels of actin mRNA remain relatively constant through $30 \mathrm{hr}$ of Fucus embryo development (Figure 1) and that there is a single copy of the actin gene in Fucus (Goodner et al., 1995).

\section{Actin mRNA Localization in the Zygote Differs from the Site of F-Actin Accumulation at the Rhizoid Tip}

We found that distribution of actin mRNA, like distribution of F-actin (Kropf et al., 1989a), is symmetrical in apolar zygotes up to $8 \mathrm{hr}$ AF (Figures $2 \mathrm{~A}$ and $2 \mathrm{~B}$ ). Controls with the actin sense probe did not exhibit color development (Figure 2F). Soon after the zygote acquires a fixed polar axis ( 8 to $10 \mathrm{hr}$ ), the first asymmetrical distribution of actin mRNA is evident (Figure $2 \mathrm{C}$ ) and becomes more pronounced during the next few hours (Fig- 


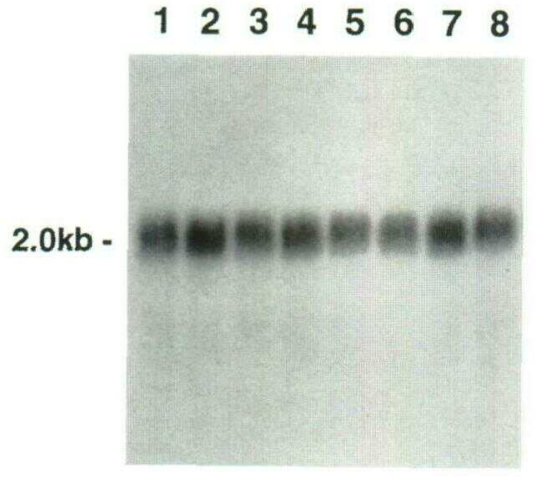

Figure 1. RNA Gel Blot Analysis of Fucus Actin Transcripts during Early Embryogenesis.

Total RNA was isolated from Fucus eggs, zygotes, and embryos, electrophoresed in a $1.2 \%$ agarose gel with $2.2 \mathrm{M}$ formaldehyde, transferred to a nylon membrane, and hybridized with a 300-nucleotide fragment of the Fucus actin A7 probe. Ten micrograms of Fucus RNA from different developmental stages was loaded in each lane: lane 1, egg; lane 2, 2-hr-old zygote; lane 3, 8-hr-old zygote; lane 4, 12-hr-old zygote; lane 5, 16-hr-old zygote; lane 6, 20-hr-old embryo; lane 7, 24-hr-old embryo; and lane 8, 30-hr-old embryo.

ure 2D). Most of the actin mRNA is in the thallus area of the polar zygote and is often distributed in a gradient, with the highest concentration detected at the thallus pole (Figure 2E). Hence, at about the same time that $\mathrm{F}$-actin accumulates at the tip of the emerging rhizoid, actin mRNA locates toward the opposite pole of the zygote. The distribution of actin mRNA at this stage of development is identical to the pattern observed for FcpA mRNA and poly(A)+ RNA (Bouget et al., 1995b).

\section{Actin mRNA Localization at the Thallus Pole of the Zygote Requires Polar Axis Fixation and Intact Microfilaments}

Using actinomycin $D(A D)$, which stops transcription within $1 \mathrm{hr}$ after addition to Fucus zygotes (Quatrano, 1968), we showed that the actin mRNA that accumulates at the thallus pole is synthesized earlier. Treatment with AD from 6 to $15 \mathrm{hr}$ AF did not interfere with the establishment of a gradient of actin mRNA (Table 1). This result indicates that actin mRNA synthesized in the egg or before $6 \mathrm{hr} A F$ is redistributed several hours later into a gradient of actin mRNA. Furthermore, transcription of the actin gene did not appear to be required at the time when actin mRNA asymmetry was observed.

Treatment with $\mathrm{CB}$, which disrupts microfilament organization (MacLean-Fletcher and Pollard, 1980) and polar axis fixation (Quatrano, 1973), disrupted the gradient of actin mRNA from 6 hr AF (Table 1). However, when 14-hr-old zygotes were incubated in $C B(100 \mu \mathrm{g} / \mathrm{mL})$, the already present gradient of actin mRNA was not disrupted (Table 1). Hence, microfila- ments and a fixed polar axis are required for the initial actin mRNA asymmetry, but components other than microfilaments may be involved in anchoring or stabilizing localized actin transcripts.

Like $\mathrm{CB}$, sucrose treatment prevents polar growth of the rhizoid, but unlike $\mathrm{CB}$, sucrose does not interfere with the establishment of a polar axis (Torrey and Galun, 1970; Quatrano, 1973). In sucrose-treated zygotes, actin mRNA was asymmetrically localized at the thallus pole, even in the absence of polar growth of the rhizoid (Table 1). Treatment with nocodozole, a microtubule inhibitor, from 6 to $15 \mathrm{hr}$ AF had no effect on the establishment of actin mRNA asymmetry or
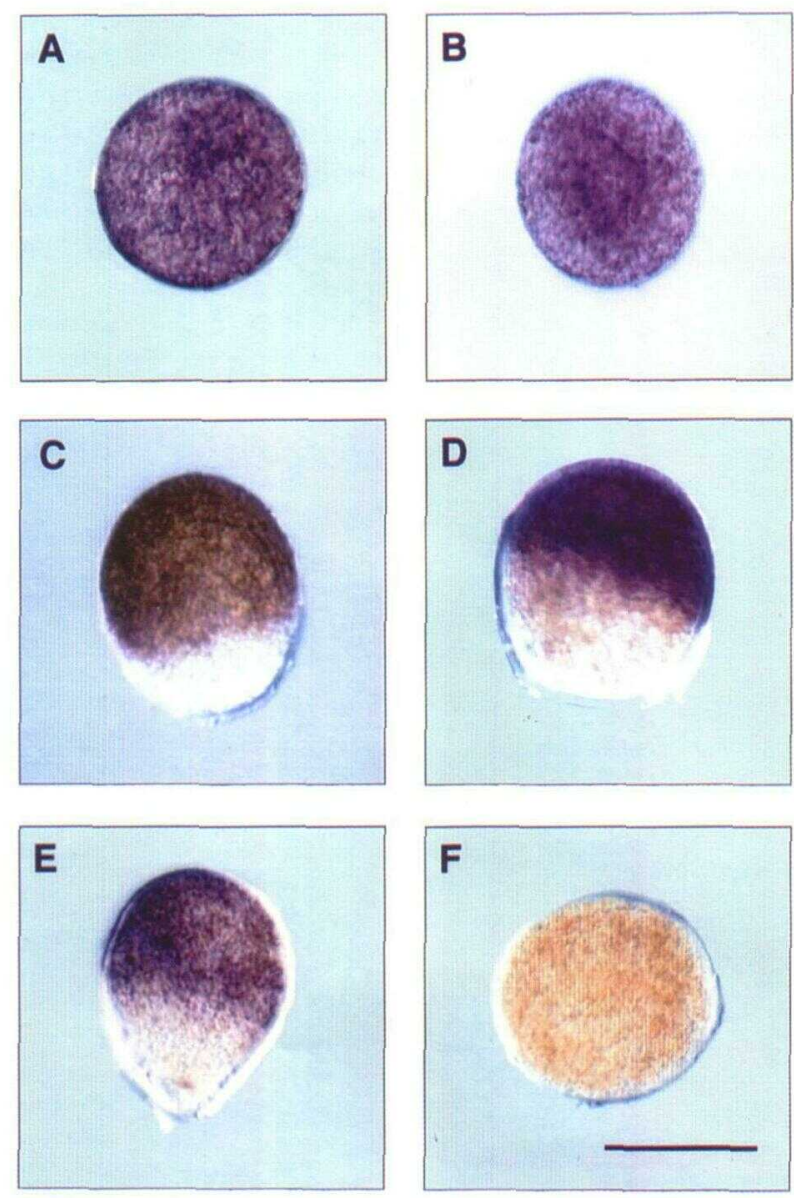

Figure 2. In Situ Localization of Actin mRNA in Early Fucus Zygotes.

Fucus zygotes were hybridized with the antisense A7 probe from the Fucus actin coding region in (A) to $(E)$ or to the sense control probe in $(\mathbf{F})$.

(A) Actin mRNA localization in a 2-hr-old zygote.

(B) Actin mRNA localization in an 8-hr-old zygote.

(C) Actin mRNA localization in a 10-hr-old zygote.

(D) Actin mRNA localization in a 12-hr-old zygote.

(E) Actin mRNA localization in a 16-hr-old zygote.

(F) Eight-hour-old zygote negative control hybridized to the actin sense probe. Bar in $(\mathbf{F})=60 \mu \mathrm{m}$. 
on its stabilization later (Table 1). Because nocodozole prevents cell division by depolymerizing microtubules (Brawley and Quatrano, 1979b; Kropf et al., 1990) but does not disrupt the redistribution of actin mRNA, it appears that the establishment and stabilization of actin mRNA asymmetry are not dependent upon intact microtubules.

\section{Actin mRNA Localization at the First Division Plane Requires the Formation of the Cell Plate}

Actin mRNA remains distributed in a gradient before and immediately after the plate of division is first discernible (Figures $3 \mathrm{~A}$ and $\mathrm{BB}$ ). Later, however, when the first division plane becomes more pronounced, additional accumulation of actin mRNA occurs at this site (Figures $3 C$ and $3 D$ ). When we compare the localization of actin mRNA at the cell plate in two-celled embryos with the pattern of F-actin protein deposition (Figure 4 ), it is clear that colocalization of actin mRNA and protein occurs only at the cell plate and not at the rhizoid tip. Localization of actin mRNA at the cell plate is specific because total poly $(A)^{+}$RNA and FcpA mRNA still exhibit high concentrations in the thallus cell but not at the division site (Figures $3 \mathrm{~F}$ and $3 G$ ). Hybridization with sense probes for actin and $F_{c p} A$

Table 1. Effects of Inhibitors on Fixation of the Polar Axis, Polar Growth, and Formation of an Actin mRNA Gradient in Zygotes ${ }^{\mathrm{a}}$

\begin{tabular}{|c|c|c|c|}
\hline Treatment & $\begin{array}{l}\text { Fixed } \\
\text { Polar } \\
\text { Axis }^{b}\end{array}$ & $\begin{array}{l}\text { Polar } \\
\text { Growth }\end{array}$ & $\begin{array}{l}\text { Actin } \\
\text { mRNA } \\
\text { Gradient }^{\circ}\end{array}$ \\
\hline Control & +++ & +++ & +++ \\
\hline $\begin{array}{l}\text { AD } \\
\qquad(20 \mu \mathrm{g} / \mathrm{mL} \text { added at } 6 \mathrm{hr})\end{array}$ & +++ & +++ & +++ \\
\hline $\begin{array}{l}\text { CB } \\
(20 \mu \mathrm{g} / \mathrm{mL} \text { added at } 6 \mathrm{hr})\end{array}$ & + & + & + \\
\hline $\begin{array}{l}\text { CB } \\
\qquad(50 \mu \mathrm{g} / \mathrm{mL} \text { added at } 6 \mathrm{hr})\end{array}$ & - & - & - \\
\hline $\begin{array}{l}\text { CB } \\
(100 \mu \mathrm{g} / \mathrm{mL} \text { added at } 14 \mathrm{hr})\end{array}$ & +++ & +++ & +++ \\
\hline $\begin{array}{l}\text { Sucrose } \\
(0.6 \mathrm{M} \text { added at } 2 \mathrm{hr})\end{array}$ & +++ & ++ & +++ \\
\hline $\begin{array}{l}\text { Nocodozole } \\
\qquad(0.2 \mu \mathrm{g} / \mathrm{mL} \text { added at } 6 \mathrm{hr})\end{array}$ & +++ & +++ & +++ \\
\hline
\end{tabular}

a The relative number of zygotes exhibiting a particular response is noted as follows: $(+++),>95 \% ;(++), \sim 50 \% ;(+),<30 \%$; or $(-)$, $<5 \%$ of the zygotes.

b The ability to fix an axis of polarity in response to unidirectional light as assayed by Quatrano (1973) and Kropf et al. (1989b).

c The length of the rhizoid measured at $15 \mathrm{hr}$ AF, except for sucrosetreated embryos that were measured at $30 \mathrm{hr}$.

${ }^{d} A$ gradient of actin mRNA as determined by in situ hybridization at $15 \mathrm{hr}$ AF, except for sucrose-treated embryos that were measured at $30 \mathrm{hr}$.
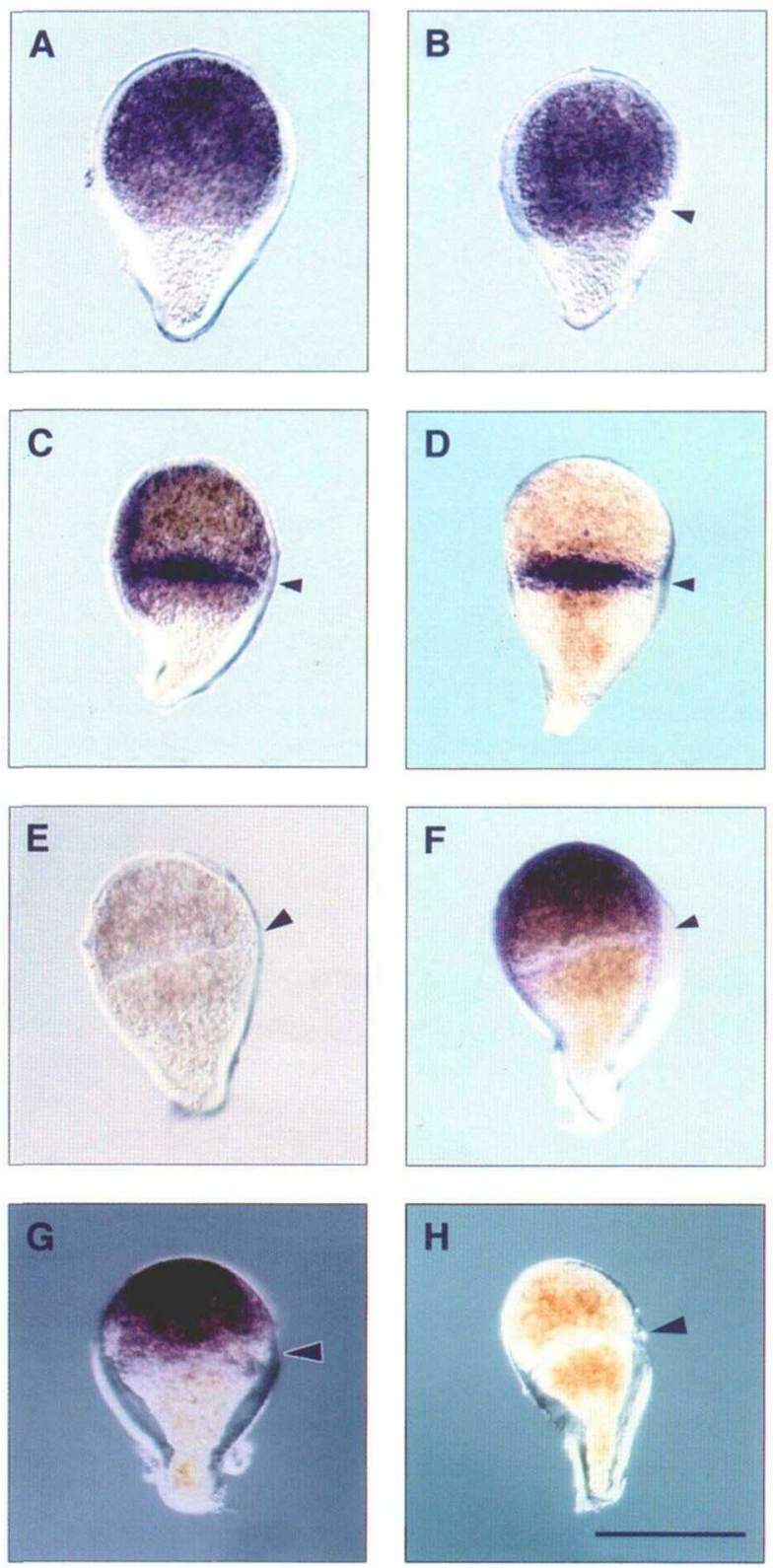

Figure 3. In Situ Localization of Actin mRNA in Dividing Zygotes and Two-Celled Embryos.

Fucus zygotes and embryos were hybridized with the antisense A7 probe from the Fucus actin coding region in (A) to (D) or to the sense control probe in $(\mathbf{E})$. Twenty-four-hour-old embryos were also hybridized to an oligo(dT) probe in (F), to the antisense riboprobe from FcpA in (G), or to the FCpA sense control probe in $(\mathbf{H})$.

(A) Actin mRNA localization in a 19-hr-old zygote (before cytokinesis).

(B) Actin mRNA localization in a 20 -hr-old newly divided zygote.

(C) Actin mRNA localization in a 22-hr-old embryo.

(D) Actin mRNA localization in a 24-hr-old embryo.

(E) Twenty-four-hour-old embryo as a negative control hybridized to the actin sense probe.

(F) Poly $(A)^{+}$RNA localization in a 24-hr-old embryo. 


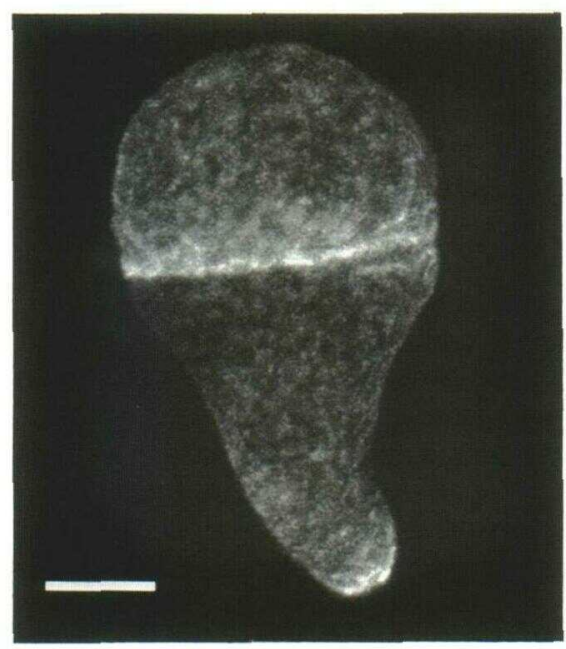

Figure 4. Actin Protein Localization in a Two-Celled Fucus Embryo at $25 \mathrm{hr} \mathrm{AF}$.

F-actin is localized primarily at the rhizoid tip and in the region of the cell plate. Bar $=25 \mu \mathrm{m}$.

mRNAs did not exhibit staining (Figures $3 E$ and $3 \mathrm{H}$ ). Treatments with $\mathrm{RNase} \mathrm{H}$ after hybridization to the oligo(dT) probe also removed the hybridization signal (Bouget et al., 1995b), indicating that the signal is specific for RNA.

When young zygotes are treated with sucrose (Torrey and Galun, 1970) or exposed to low doses of CB $(20 \mu \mathrm{g} / \mathrm{mL})$, polar growth of the rhizoid is inhibited, whereas cytokinesis is partially inhibited by CB but not by sucrose. In the absence of polar growth, the first division of these treated embryos is symmetrical, but the localization of actin mRNA is still found at the cell plate (Figures $5 \mathrm{~A}$ and $5 \mathrm{~B}$ ). Hence, the localization of actin mRNA at the cell plate does not require polar growth or an asymmetric division.

Treatment of 15-hr-old zygotes with AD did not prevent actin mRNA localization at the cell plate (Table 2), indicating that the actin mRNA detected at this site was present in the zygote at least $9 \mathrm{hr}$ before becoming localized. CB $(100 \mu \mathrm{g} / \mathrm{mL})$ or nocodozole $(0.2 \mu \mathrm{g} / \mathrm{mL})$ applied immediately after cell division (20 hr AF), but before actin mRNA localization to the cell plate (cf. Figure 3B), did not inhibit actin mRNA accumulation to this site $24 \mathrm{hr} \mathrm{AF}$ (Table 2). CB and nocodozole were both active at $24 \mathrm{hr}$ AF because further incubation of embryos with either drug inhibited the next cell division (data not shown). Hence,

Figure 3. (continued).

(G) FcpA mRNA localization in a 24-hr-old embryo.

(H) Twenty-four-hour-old embryo negative control hybridized to the FcpA sense probe.

Arrowheads indicate the division planes. Bar in $(\mathbf{H})=60 \mu \mathrm{m}$. the mechanism of actin mRNA localization to the cell plate from the thallus pole appears to be independent of intact microfilaments or microtubules.

To investigate whether cytokinesis is required for the specific localization of actin mRNA at the division site, we treated undivided zygotes with caffeine, a drug that prevents cell plate formation after a normal karyokinesis in higher plants (Hepler and Bonsignore, 1990). Thirty-five percent of the zygotes did not divide in $1.5 \mathrm{mM}$ caffeine, and $85 \%$ did not undergo division in $4.5 \mathrm{mM}$ caffeine (Figure 6). Interestingly, for all concentrations of caffeine tested, $\sim 15 \%$ of the embryos exhibited a partial division that originated from one side or the other of the zygotic cell wall (Figure 6). Caffeine-treated zygotes that did not divide did not exhibit any specific localization of actin mRNA at the presumptive cell plate (Table 2). Under these same conditions, actin mRNA remained distributed in a gradient concentrated at the thallus pole (Figure $3 \mathrm{~A}$ ). Caffeine-treated zygotes that divided also displayed an accumulation of actin mRNA at the division site (Table 2), as shown in Figure 3D. However, in those zygotes that underwent partial cytokinesis, actin mRNA accumulated only where the cell plate was formed (Figures 7A and 7B). Incubation with nocodozole $(0.2 \mu \mathrm{g} / \mathrm{mL}$ ) from $6 \mathrm{hr}$ AF resulted in a polar zygote with a rhizoid but without any cell plate formation (Kropf et al., 1990). Under these conditions, actin mRNA remained localized at the thallus pole in a gradient (Figure $3 \mathrm{~A}$ ) and did not accumulate where the cell plate would usually form (Table 2). These results with caffeine and nocodozole indicate that formation of the cell plate, even if incomplete, is necessary for actin mRNA accumulation at the first division site.
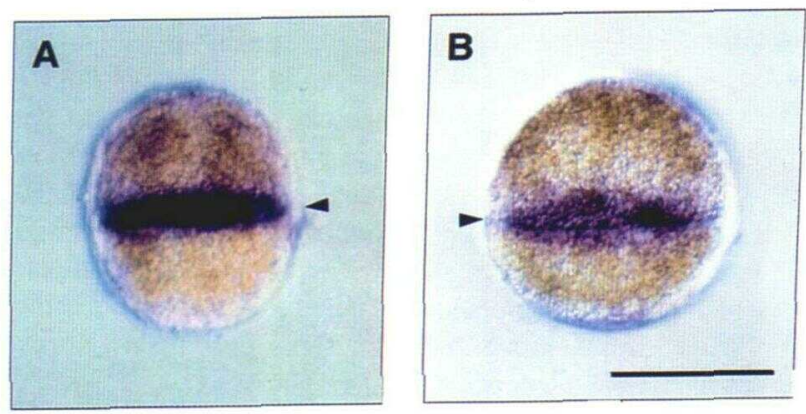

Figure 5. In Situ Localization of Actin mRNA in Spherical Two-Celled Embryos.

Incubations with CB and sucrose both produced morphologically symmetrical embryos that were hybridized to the antisense $A 7$ probe from the Fucus actin coding region. Hybridization with the actin sense control probe did not result in any staining (data not shown).

(A) Actin mRNA localization in a 24-hr-old apolar embryo that was treated with $\mathrm{CB}(20 \mu \mathrm{g} / \mathrm{mL})$ continuously from $6 \mathrm{hr}$ AF.

(B) Actin mRNA localization in an embryo with a fixed polar axis (the same developmental stage as shown in [A]) that was treated with 0.6 $\mathrm{M}$ sucrose continuously from $2 \mathrm{hr}$ AF.

Arrowheads indicate the division planes. Bar in $(B)=60 \mu \mathrm{m}$. 
Table 2. Effects of Inhibitors on Cell Division and Actin mRNA Localization at the Cell Plate in Two-Celled Embryos ${ }^{a}$

\begin{tabular}{lll} 
Treatment & $\begin{array}{l}\text { Cell } \\
\text { Division }\end{array}$ & $\begin{array}{l}\text { Actin mRNA } \\
\text { at the } \\
\text { Cell Plate }\end{array}$ \\
\hline $\begin{array}{l}\text { Control } \\
\text { AD }\end{array}$ & +++ & +++ \\
$(20 \mu \mathrm{g} / \mathrm{mL}$ added at $15 \mathrm{hr})$ & +++ & +++ \\
$\begin{array}{l}\text { Nocodozole } \\
(0.2 \mu \mathrm{g} / \mathrm{mL} \text { added at } 6 \mathrm{hr})\end{array}$ & - & - \\
$\begin{array}{l}\text { CB } \\
(100 \mu \mathrm{g} / \mathrm{mL} \text { added at } 20 \mathrm{hr})\end{array}$ & +++ & +++ \\
$\begin{array}{l}\text { Nocodozole } \\
(0.2 \mu \mathrm{g} / \mathrm{mL} \text { added at } 15 \mathrm{hr})\end{array}$ & +++ & +++ \\
$\begin{array}{l}\text { Caffeine } \\
(1.5 \mathrm{mM} \text { added at } 19 \mathrm{hr})\end{array}$ & ++ & ++ \\
Caffeine & & + \\
$(4.5 \mathrm{mM}$ added at $19 \mathrm{hr})$ & + & + \\
\hline
\end{tabular}

a The relative number of zygotes exhibiting a particular response is noted as follows: $(+++),>95 \% ;(++), \sim 50 \% ;(+),<30 \%$; or $(-)$, $<5 \%$ of the zygotes.

${ }^{b}$ Cell division was determined by the presence of a cell plate at 24 hr AF.

c Localization of actin mRNA at the first cell plate was determined by in situ hybridization at $24 \mathrm{hr}$ AF.

\section{Actin mRNA Localizes at the Cell Plates in the Rhizoid but Not at the Site of the First Thallus Cell Division}

The second division of the embryo, which is a transverse division of the rhizoid cell, also displays a specific accumulation of actin mRNA at the cell plate (Figure 8A). The next division of the embryo occurs in the thallus cell and is perpendicular to the plane of the first division and parallel to the polar axis. This division of the thallus cell did not exhibit any accumulation of actin mRNA (Figure 8D). We have been unable to detect F-actin collars at the cell plate of this first division of the thallus cell, using the same protocol that detects F-actin collars at the cell plates of the rhizoid divisions (see Figure 4). Hybridizations with sense control probes do not stain three- and four-celled embryos (Figures $8 \mathrm{~B}$ and $8 \mathrm{E}$ ), and the localization of actin mRNA appears to be specific, because poly $(A)^{+}$RNA remains distributed in a gradient, with the highest level of accumulation in the thallus cell(s) (Figures $8 \mathrm{C}$ and $8 \mathrm{~F}$ ).

Occasionally, the thallus cell divides before the rhizoid cell, and under these conditions, localization of actin mRNA was not detected at the cell plate that separates the thallus cells (Figure 8G). Similarly, in three-celled, sucrose-treated embryos that lack a rhizoid, only the first transverse cell plate of the embryo displayed higher concentrations of actin mRNA (Figure $8 \mathrm{H})$. It appears, then, that actin mRNA specifically accumulates at the cell plates separating rhizoid cells, the site of F-actin accumulation in the form of actin collars.

\section{DISCUSSION}

\section{Redistribution of Actin mRNA in the Zygote Requires Microfilaments}

We utilized a nonradioactive, whole-mount in situ hybridization technique (Bouget et al., 1995a) to study the pattern of actin mRNA distribution in Fucus zygotes and embryos. The distribution of actin mRNA follows a distinct developmental pattern. It is first observed in a symmetrical pattern in the apolar zygote. After polar axis fixation, actin mRNA becomes localized primarily in the thallus half of the zygote and is often observed in gradient, with the highest concentration at the thallus pole. This redistribution is not unique to actin mRNA because an identical pattern has been observed for another mRNA (FcpA) and for total poly $(A)^{+}$RNA (Bouget et al., 1995b). Transcription is not required for this change in distribution because the actin mRNA, which is localized at the thallus pole, is present at least several hours earlier and may be represented in the population of mRNAs stored in the egg (Kropf et al., 1989b; Masters et al., 1992).

Using various treatments that perturb polarity, we showed that this redistribution of actin mRNA, from a symmetrical to an asymmetrical pattern, requires intact microfilaments and a fixed polar axis but does not depend on intact microtubules or polar growth of the thizoid. Other events associated with a stable polarity, that is, directed transport of Golgi vesicles (Brawley and Quatrano, 1979a), have similar requirements (see

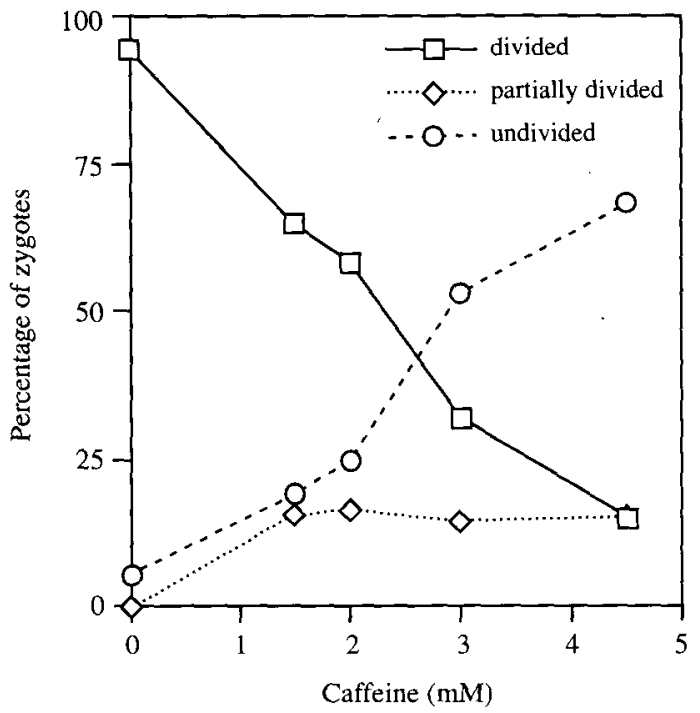

Figure 6. Inhibition of Cytokinesis by Treatments with Caffeine

Nineteen-hour undivided zygotes were incubated with caffeine at the concentrations shown. At $24 \mathrm{hr}$, the embryos were fixed for in situ hybridization and observed (see Methods). Zygotes from each class (undivided, partially divided, and divided) were scored $(n=600$ ) and reported as a function of the caffeine concentration. 

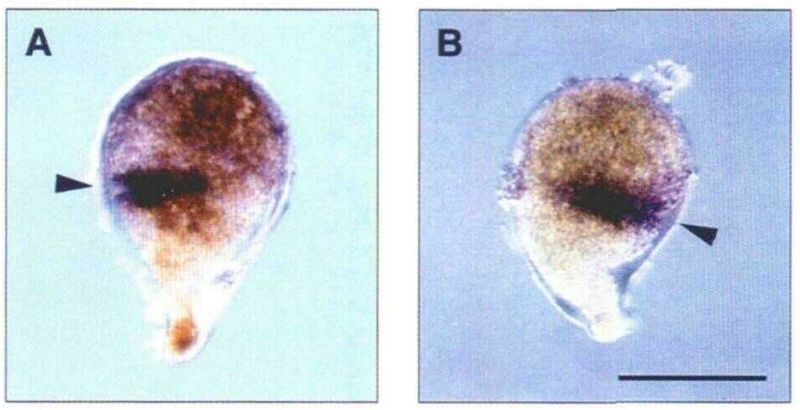

Figure 7. In Situ Localization of Actin mRNA in Caffeine-Treated Zygotes.

Caffeine-treated zygotes and embryos were hybridized with the antisense A7 probe from the Fucus actin coding region. Hybridization with the actin sense control probe did not result in any signal (data not shown).

(A) Actin mRNA localization in a partially divided embryo that was treated with $3 \mathrm{mM}$ of caffeine from 19 to $24 \mathrm{hr}$ AF.

(B) Same as shown in (A), but the division plane is more pronounced. Arrowheads indicate the division planes. Bar in $(B)=60 \mu \mathrm{m}$.

Fowler and Quatrano, 1995). Although there is no cytological evidence for polyribosome asymmetry in Fucus (Brawley et al., 1977), actin microfilaments linked to polyribosomes (see Abe et al., 1991; Davies et al., 1996) may be part of the mechanism for this mRNA asymmetry. Hence, an interaction between actin mRNA (or particles containing actin mRNA; see St. Johnston, 1995) and microfilaments may be required for the observed asymmetry in actin mRNA distribution in Fucus. Similar observations have been made for $\beta$-actin mRNA in cultured fibroblasts in which these transcripts are found near the intersections of actin filaments (Sundell and Singer, 1991).

\section{Actin mRNA Does Not Colocalize with F-Actin in the Zygote}

Our results also indicate that most of the actin mRNA that is redistributed toward the thallus pole does not colocalize with the major accumulation of F-actin at the opposite rhizoid pole. We cannot exclude completely the possibilities that, under our conditions of whole-mount in situ hybridizations and DNA gel blot analysis (Goodner et al., 1995), undetectable levels of actin transcripts are translated locally at the rhizoid site at the time of F-actin accumulation or that transcripts from another actin gene are localized but not detected. However, the pattern of actin mRNA distribution suggests that local translation of F-actin from mRNA localized at the rhizoid tip is not likely to be the principal mechanism involved in the large and persistent accumulation of F-actin at this site. Rather, the actin network that accumulates at the target site for directed vesicle transport and rhizoid emergence is more likely to be sequestered and maintained there by some mechanism(s) other than by translation of localized actin mRNA.

The F-actin that is localized at the target site for vesicle transport and polar growth of the rhizoid may be synthesized and assembled in the egg or early zygote. Although actin protein is found in the egg, all three actin isoforms in Fucus are synthesized after fertilization (Kropf et al., 1989b). Hence, it is difficult to determine whether the F-actin assembled at the rhizoid tip is synthesized during oogenesis or shortly after fertilization.

\section{Actin mRNA and F-Actin Colocalize at the Cell Plates of the First Two Divisions of the Embryo}

During completion of the first cell division of the zygote, there is a gradual and specific localization of actin mRNA at the cell plate. This is the first spatial difference observed among the distribution of poly $(A)^{+}$RNA, FcpA mRNA, and actin mRNA. The accumulation of actin mRNA at the plate separating the rhizoid from the thallus cell persists during the next division of the rhizoid cell. The second cell plate, which separates two rhizoid cells, also exhibits the specific sequestering of actin mRNA. However, the next division of the embryo is different from the previous ones. The third division is a vertical and symmetrical division of the thallus cell that does not exhibit nuclear rotation (Allen and Kropf, 1992) and lacks the large accumulation of actin mRNA at the cell plate. The fact that actin mRNA is not detected at the cell plate in the thallus cell indicates that the accumulation of actin mRNA at the cell plates separating the rhizoid cells is not a requirement for the cell division process. We know that F-actin is associated with the cytokinesis apparatus in plants (Mineyuki and Palevitz, 1990) and is likely to play a role in cell division of the Fucus embryo. However, the accumulation of actin mRNA appears to be correlated spatially with the deposition of relatively large amounts of F-actin associated with the cell plates of the rhizoid cells (see Figure $4 ;$ Kropf et al., 1992). Using the same protocol as Kropf et al. (1992), we were able to visualize actin collars at the first two division sites of the embryo but not at the third one in the thallus cell (data not shown). It appears, then, that actin mRNA specifically accumulates at the rhizoid cell plates that exhibit an accumulation of F-actin in the form of actin collars.

This result, however, needs to be carefully interpreted. The protocol of F-actin staining is based on the stabilization of the microfilaments with $\mathrm{m}$-maleimidobenzoyl $\mathrm{N}$-hydroxysuccinimide (Sonobe and Shibaoka, 1989) combined with a simultaneous soft lysis of the embryo that helps to reduce the autofluorescence and to visualize the microfilaments stained with rhodamine-phalloidin. Because the lysis occurs principally at the rhizoid tip, it is possible that in our experiment, the cytoplasm was not as well removed from the thallus cells, thus preventing detection of a potential actin collar at the thallus division site. However, even under conditions in which the thallus cell divides before the rhizoid cell (see Figure $8 \mathrm{G}$ ) or in three-celled sucrose-treated embryos that lack a rhizoid (see 

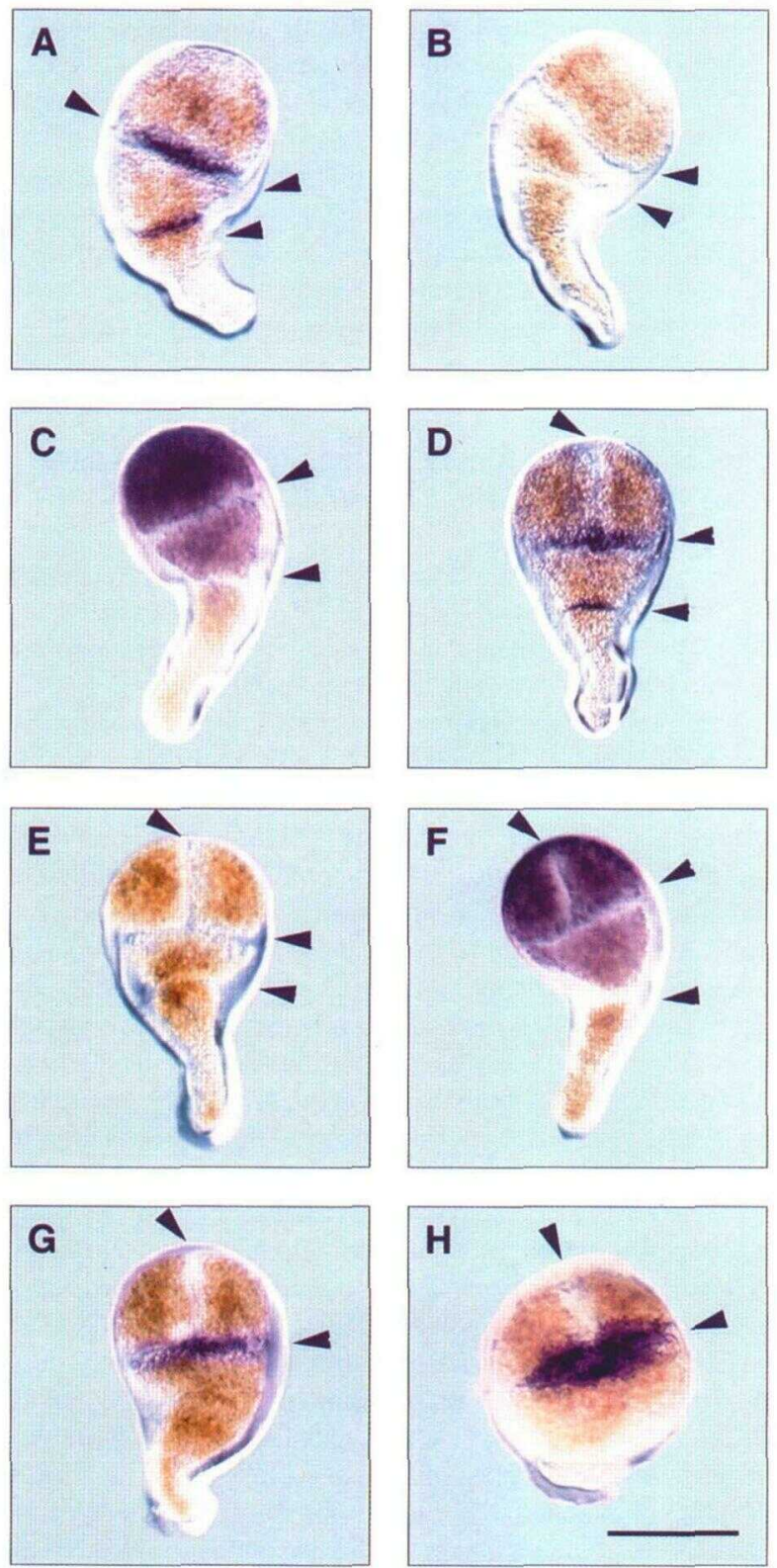

Figure 8. In Situ Localization of Actin mRNA in Three- and Four-Celled Embryos.

Fucus embryos were hybridized to the antisense $\mathrm{A} 7$ riboprobe from the Fucus actin coding region in (A), (D), (G), and $(\mathbf{H})$, to the actin sense control probe in (B) and (E), or to an oligo(dT) probe in (C) and (F).

(A) Actin mRNA localization in a 28-hr-old embryo.

(B) Twenty-eight-hour-old embryo as a negative control hybridized to the actin sense probe.

(C) Poly $(A)^{+}$mRNA localization in a 28 -hr-old embryo.

(D) Actin mRNA localization in a 32-hr-old embryo.

(E) Thirty-six-hour-old embryo as a negative control hybridized to the actin sense probe.

(F) Poly(A) ${ }^{+}$mRNA localization in a 32-hr-old embryo.
Figure $8 \mathrm{H}$ ), only the first transverse cell plate and not the second vertical cell plate of the embryo displayed higher concentrations of actin mRNA.

The function of F-actin as actin collars at the rhizoid cell plates is not known. Because the actin collar persists long after the division has occurred (Kropf et al., 1992), it may play a structural role in strengthening the filamentous rhizoid that serves as an attachment structure for the developing plant rather than playing a direct role in the cell division process. In any case, the actin collar seems to be a feature of the cell plates that form after asymmetrical cell divisions of the rhizoid cell and, coupled with nuclear rotation, gives rise to the characteristic rhizoid filament. Traas et al. (1987) also suggest that the actin associated with the phragmoplast in carrot suspension-cultured cells may be involved in nuclear positioning. It would be of interest to determine whether colocalization of F-actin and actin mRNA at these sites in the rhizoid is characteristic of cytokinesis only in filaments of Fucus or is characteristic of similar asymmetric divisions or filamentous growth in other plant cells.

\section{Actin mRNA Localization and Stabilization at the Rhizoid Division Sites Require the Cell Plate but Not the Cytoskeleton}

Our results with $A D$ indicate that some of the actin mRNA that is localized at the cell plate is synthesized before the zygote divides. Also, our data suggest that the transport and/or stabilization of actin mRNA at the division site does not require transcription or cytoskeletal elements. Furthermore, the pattern of actin mRNA localization at the first cell plate is independent of polar outgrowth because certain treatments with $\mathrm{CB}$ or sucrose result in two-celled spherical embryos that exhibit the same localization of actin mRNA. Hence, the specific localization pattern of actin mRNA at the division site appears to be independent of the initial polarization events and more closely associated with the formation of the first two division plates of the developing embryo.

Fucus cytokinesis is unique and different from higher plant cytokinesis because it occurs without a preprophase band, exhibits centripetal growth of the cross wall, and lacks a typical phragmoplast (Brawley et al., 1977; Kropf et al., 1990). These early divisions of the young embryo are also unlike other divisions in mature vegetative tissue of Fucus because plas-

(G) Actin mRNA localization in a 28-hr-old embryo with the second cell division in the thallus ( $<5 \%$ of the three-celled embryos have their second division in the thallus cell).

(H) Actin mRNA localization in a 60-hr-old embryo that was treated with $0.6 \mathrm{M}$ sucrose from $2 \mathrm{hr}$ until $60 \mathrm{hr}$ AF.

Arrowheads indicate the division planes. Bar in $(H)=65 \mu \mathrm{m}$. 
modesmata have not been observed in the cross walls. Furthermore, Brawley et al. (1977) described the formation of a unique "partition membrane." This membrane initially separates the first two daughter cells and does not appear to arise from the fusion of Golgi vesicles. Later, the partition membrane is the site of cell wall deposition forming the cell plate. However, even considering these differences, both caffeine and nocodozole function as they do in higher plant cells, that is, they prevent cytokinesis. Using these inhibitors, we showed that the formation of the cell plate is necessary for actin mRNA localization and/or stabilization. Interestingly, in some caffeinetreated embryos, cytokinesis is only partially completed, and we observed that actin mRNA accumulation occurs only at the site at which the cell plate forms (see Figure 7). It might be worthwhile to determine whether actin mRNA is also localized at the cell plate in Spirogyra, which has a type of cell plate formation that is "intermediate" between Fucus and higher plants, that is, centripetal growth of the crosswall but a small phragmoplast (Mclntosh et al., 1995).

\section{Possible Mechanisms for Actin mRNA Localization in the Embryo}

Most of the well-known examples of mRNA localization in animal cells (see St. Johnston, 1995) involve a mechanism(s) requiring either microtubules (Pokrywka and Stephenson, 1991) and/or microfilaments (Yisraeli et al., 1990; Sundell and Singer, 1991) and specific sequences in the $3^{\prime}$ untranslated region to direct the proper transport of localized mRNAs (Kislauskis and Singer, 1992). However, neither intact microfilaments nor microtubules seem to be required for actin mRNA localization at the rhizoid cell plate of Fucus because high doses of $C B$ or nocodozole, when given immediately after cell division, did not prevent the redistribution of actin mRNA from the thallus pole to the cell plate. Hence, the mechanism for actin mRNA localization at the cell plate appears to be different from the mechanism responsible for the redistribution of actin mRNA (and most other mRNAs) from a symmetrical pattern in the egg and early zygote to the thallus pole in zygotes with a fixed polar axis. Our results also indicated that this pattern of actin mRNA distribution in both the zygote and embryo is not likely to be explained by changes in the level of actin mRNA or segregation of a specific member of an actin gene family. Steady state levels of actin mRNA are constant, and only one copy of the actin gene is represented in the Fucus genome (Goodner et al., 1995). Rather, mechanisms that are responsible involve the redistribution of transcripts from the actin gene that accumulate much earlier, either in the egg or early zygote. It is possible, however, that different isoforms of F-actin (Kropf et al., 1989b) are localized to different sites in the Fucus embryo.

Models can be proposed to explain the localization of actin mRNA at the rhizoid division sites that require the formation of a cell plate but do not involve the cytoskeleton. Mechanisms for the selective degradation of MRNA appear to be involved in the localization of hunchback mRNA in Drosophila (Wharton and Struhl, 1991) and for germline mRNAs in Caenorhabditis elegans (Seydoux and Fire, 1994). A similar mechanism may be operative in Fucus, that is, one that selectively degrades actin transcripts not associated with the cell plate. However, if this were a mechanism in Fucus, the amount of degradation would be small because there is no appreciable decrease in total actin mANA (see Figure 1). Another possibility would be the diffusion of free actin mRNA (Luby Phelphs, 1994) to the cell plate, followed by the selective anchoring to specific membrane sites associated within the cell plate region, for example, the partition membrane observed by Brawley et al. (1977). Targeting and stabilization of mRNA to distinct domains of such a membrane may be similar to that observed by Li et al. (1993) for storage protein transcripts in rice endosperm cells. By high resolution in situ hybridization techniques, they observed that two rough endoplasmic reticulum (ER) types, the cisternal ER and protein body ER, have significantly different glutelin and prolamine mRNA transcripts. A sorting of these mRNAs to spatially separated domains of the ER may be an important mechanism in this segregation process. This mechanism of diffusion, followed by anchoring to localized binding sites, resembles that suggested for the nanos, cyclin B, or gc/1 mRNAs in Drosophila oocytes (Raff et al., 1990; Jongens et al., 1992; Wang et al., 1994). Both the selective degradation and selective anchoring models for Fucus require binding to the cell plate region, perhaps involving the partition membrane. Recent success in following fluorescently labeled actin protein by confocal microscopy after microinjection into Fucus zygotes (see figure 2F in Fowler and Quatrano, 1995) may allow us to follow actin mRNA accumulation directly to the cell plate.

\section{Significance of the Pattern of Actin mRNA Localization in Fucus Embryos}

Colocalization of actin mRNA with F-actin at the rhizoid cell plates indicates that mRNA localization may be a mechanism operative in plants for the local accumulation of proteins, as are the results of Li et al. (1993) described above. Colocalization of mRNAs and proteins for cytoskeletal proteins has been observed in animal embryos and differentiated cells (see Fulton, 1993). Strong evidence suggests that mRNA segregation and local translation could spatially facilitate the assembly of some cytoskeletal proteins and help to maintain the cytoskeleton structure (St. Johnston, 1995), perhaps by locally achieving a high concentration of protein (Wilhelm and Vale, 1993). Whereas the actin mRNA becomes localized at the first cell plate of the Fucus embryo after the cytokinesis is completed, F-actin seems to accumulate at the same site shortly before cell division (Kropf, 1994). Hence, the local accumulation of actin mRNA may contribute to the maintenance of the actin collar rather than to its initial elaboration. This is similar to the localization of vimentin protein, which precedes the localiza- 
tion of its mANA in myoblasts (Cripe et al., 1993). It would be of interest to determine the distribution pattern of another cytoskeletal gene from Fucus, for example, tubulin.

However, localization of actin mRNA is not the only mechanism that can account for the localization pattern of F-actin in Fucus embryos. We show in this study that actin mRNA does not localize at the site of the major accumulation of F-actin at the tip of the elongating rhizoid. This localization of F-actin is clearly involved in the establishment and maintenance of the polar axis and appears to become localized by some other mechanism. Hence, in the two- and three-celled Fucus embryos, two different mechanisms may account for the unique pattern of F-actin distribution.

The pattern and requirements for actin mRNA localization in the Fucus embryo may be relevant to polarization of higher plant embryos. The pattern of early cell divisions in the Fucus embryo is identical to those of higher plant embryos, such as Arabidopsis. For example, the first division is asymmetric in which a smaller cell (the rhizoid cell in Fucus and the basal cell in Arabidopsis) undergoes several more divisions, resulting in a filament (the rhizoid in Fucus and the suspensor in Arabidopsis). The cells within these filaments are terminally differentiated and do not become part of the embryo proper. There is no evidence for localized cytoplasmic determinants operative in the differentiation of rhizoid or thallus cells, but increasing evidence exists for positional information being stored in the cell wall (Kropf et al., 1988; Berger et al., 1994). Similarly, a number of studies in higher plants indicate that positional information rather than segregation of intracellular determinants plays a more critical role in early plant development (Poethig, 1989). It would be of interest to determine whether the pattern of poly $(A)^{+}$RNA and actin mRNA localization observed in Fucus is similar to other wild-type and mutant embryos of Arabidopsis (Mayer et al., 1993; Torres-Ruiz and Jürgens, 1994). Also, determining whether nonembryonic plant cells exhibiting tip growth or asymmetric cell divisions exhibit similar patterns of mRNA localization could lead to a better understanding of these processes. Furthermore, studies on mRNA localization in higher plants may uncover a pattern that could reflect differences in the developmental pattern of early embryogenesis between plants and other organisms that undergo a more lineage-dependent pattern of development, for example, C. elegans (see Seydoux and Fire, 1994).

\section{METHODS}

\section{Plant Material and Inhibitor Treatments}

Mature receptacles of Fucus distichus were collected from Newport, Oregon, and stored at $4^{\circ} \mathrm{C}$ for up to 2 weeks. Gametes were released into artificial seawater (ASW) (450 mM NaCl, $10 \mathrm{mM} \mathrm{KCl}, 9 \mathrm{mM} \mathrm{CaCl}_{2}$, $30 \mathrm{mM} \mathrm{MgCl}_{2}, 16 \mathrm{mM} \mathrm{MgSO}_{4}$, and $10 \mathrm{mM}$ Tes, $\mathrm{pH} 7.5$ ) over a period of $1 \mathrm{hr}$ by standard procedures using osmotic shock (Quatrano, 1980).
Embryos were collected, washed in ASW, dispensed into 15-mm plastic Petri dishes, and grown at $17^{\circ} \mathrm{C}$.

The role of the cytoskeleton in the distribution of actin mRNA was investigated by using cytochalasin B (CB) (50 or $100 \mu \mathrm{g} / \mathrm{mL}$; Sigma) and nocodozole $(0.2 \mu \mathrm{g} / \mathrm{mL}$; Sigma). $\mathrm{CB}$ and nocodozole were dissolved in DMSO at 25 and $2 \mathrm{mg} / \mathrm{mL}$, respectively, and later diluted in ASW. The zygotes were incubated with these inhibitors either from an early stage (0 to $6 \mathrm{hr}$ after fertilization [AF]) until they were placed in fixative at 16 or $24 \mathrm{hr}$, or from a later stage (16 hr AF) until after cell division (24 hr AF). Control experiments were performed in ASW containing the same concentrations of DMSO. Treatments with actinomycin $D$ (AD) $(20 \mu \mathrm{g} / \mathrm{mL}$; Sigma) were from 6 or $15 \mathrm{hr}$ AF until fixation of the cells at 15 or $24 \mathrm{hr}$, respectively.

The role of polar growth of the rhizoid in mRNA localization was investigated by incubating the zygotes in sucrose $(0.6 \mathrm{M})$. This high osmolarity medium inhibits rhizoid outgrowth and delays cell division (Kropf et al., 1990) without affecting polar axis fixation (Quatrano, 1973). Treatments began at $2 \mathrm{hr}$ AF until fixation of single-celled zygotes at $30 \mathrm{hr}$ (equivalent to a 15-hr-old developmental stage) or of two-celled embryos at $48 \mathrm{hr}$ (equivalent to a 24-hr-old developmental stage). The role of cytokinesis in mRNA localization was investigated by incubating zygotes from 19 ( $1 \mathrm{hr}$ before the first cell division) to $24 \mathrm{hr}$ AF in different concentrations of caffeine. The effect of different concentrations of caffeine (diluted with ASW from a stock of $100 \mathrm{mg} / \mathrm{mL} \mathrm{ASW}$; Sigma) was tested on samples of at least 600 zygotes.

\section{RNA Analysis}

Unfertilized eggs were harvested at $0^{\circ} \mathrm{C}$ in ASW without calcium, according to Kropf et al. (1989a), whereas fertilized zygotes were allowed to develop in ASW from 0 to $30 \mathrm{hr}$ AF. Total embryonic RNA was purified by hexadecyltrimethylammonium bromide (CTAB) extraction and $\mathrm{LiCl}$ precipitation (Apt et al., 1995) and assayed by blot hybridization using standard procedures (Sambrook et al., 1989). High-stringency hybridization and washes were performed with Zeta Probe GT blotting membrane (Bio-Rad), according to the manufacturer's recommendations. The actin probe (A7) consisted of a 300-bp cDNA fragment from within the coding region of the actin gene of Fucus cloned into the plasmid pCRII (Invitrogen, San Diego, CA).

\section{Fixation of Plant Material}

Zygotes or embryos were collected from the Petri dish and allowed to settle into $50-\mathrm{mL}$ conical tubes. ASW was replaced with $15 \mathrm{~mL}$ of fixative solution ( $4 \%$ paraformaldehyde, $80 \mathrm{mM}$ Pipes, $\mathrm{pH} 7.4,5 \mathrm{mM}$ EGTA, $5 \mathrm{mM} \mathrm{MgCl}_{2}, 20 \%$ glycerol). After $45 \mathrm{~min}$, the fixative was removed, and the zygotes were washed three times, for $5 \mathrm{~min}$ each, in a solution of $80 \mathrm{mM}$ Pipes, $\mathrm{pH} 7.4,45 \mathrm{mM} \mathrm{NaCl}, 20 \%$ glycerol. Pigments were removed with methanol (five changes, 5 min each at room temperature). Ethanol was substituted for methanol in the final wash, and the cells were stored at $-20^{\circ} \mathrm{C}$ for up to 3 weeks before hybridization.

\section{Preparation of the Probes for in Situ Hybridization}

The plasmids carrying $A 7$ and FcPA cDNAs were linearized appropriately for either SP6, T7, or T3 polymerase-directed RNA synthesis. 
Synthesized RNA was labeled by incorporating digoxigenin (DIG)conjugated UTP, as recommended by the manufacturer (Boehringer Mannheim). The following solutions were added to $1 \mu \mathrm{g}$ of linearized template: $2 \mu \mathrm{L}$ of a $10 \mathrm{mM}$ nucleotide mix (including $3.5 \mathrm{mM}$ labeled UTP and $6.5 \mathrm{mM}$ unlabeled UTP), $4 \mu \mathrm{L}$ of $5 \times$ transcription reaction buffer (supplied with kit), $2 \mu \mathrm{L}$ of $100 \mathrm{mM}$ DTT, $0.5 \mu \mathrm{L}$ of RNasin (Promega, Madison, WI), $2 \mu \mathrm{L}$ of the specific polymerase, and $8 \mu \mathrm{L}$ of $\mathrm{H}_{2} \mathrm{O}$. After $2 \mathrm{hr}$ at $37^{\circ} \mathrm{C}, 2 \mu \mathrm{L}$ of DNase I (RNase free; Boehringer Mannheim) was added to digest the DNA template. FcpA sense and antisense mRNAs were subjected to alkaline hydrolysis (Cox et al., 1984 ) to reduce their size to $<300$ nucleotides. Both actin and $F_{C} P A$ mRNAs were precipitated and resuspended in $100 \mu \mathrm{L}$ of $\mathrm{H}_{2} \mathrm{O}$, and typically, $\sim 5 \mu \mathrm{L}(500 \mathrm{ng}$ ) of the labeled product was used in $0.5 \mathrm{~mL}$ of hybridization solution. The distribution of poly $(A)^{+}$RNA was determined with a 55-nucleotide oligo(dT), $5^{\prime}$ end labeled with DIG dUTP (100 $\mathrm{ng}$ of probe in $0.5 \mathrm{~mL}$ ) (Bouget et al., 1995b).

\section{In Situ Hybridization}

The nonradioactive whole-mount in situ hybridization protocol we developed for Fucus (Bouget et al., 1995a) is based on the technique described by Ludevid et al. (1992), adapted from Tautz and Pfeifle (1989), and modified accordingly. Postfixation buffers contained $4 \%$ paraformaldehyde instead of $5 \%$ formaldehyde. Hemo-De (Fisher Scientific, Pittsburgh, PA) was substituted for xylene. To prevent plasmolysis, osmotic changes were done gradually from methanol to fixation solution during the first postfixation step and later from PBS containing $0.1 \%$ Tween 20 to hybridization solution (3:1, 1:1, and 1:3 [v/v]). Hybridization and the following washes were performed at $55^{\circ} \mathrm{C}$ for the $\mathrm{A} 7$ antisense and sense probes and $37^{\circ} \mathrm{C}$ for the oligo(dT) probe. A partial digestion of the cell wall was performed with 1 unit $/ \mathrm{mL}$ of alginate lyase for $6 \mathrm{hr}$ at $17^{\circ} \mathrm{C}$. This step enabled the alkaline phosphatase conjugate anti-DIG antibody to penetrate the embryo. Finally, the degradation of the unhybridized probe with $20 \mathrm{ng} / \mathrm{mL}$ of RNase A (Boehringer Mannheim) reduced subsequent nonspecific staining and consequently allowed longer chromogenic reaction times (from 2 to $6 \mathrm{hr}$ ). Controls without either the probe or antibody did not result in a positive signal, indicating the specificity of the probe and the lack of endogenous alkaline phosphatase activity. Controls were also included in the figures for the sense probes for both actin and FCpA, and RNase for the oligo(dT) probe (Bouget et al., 1995b).

\section{Localization of F-Actin Protein}

Actin filaments were visualized with fluorescein-phalloidin (Sigma). Zygotes were washed one time with buffer A (25 mM Pipes, $1 \mathrm{mM}$ $\mathrm{MgSO}_{4}, 1 \mathrm{mM}$ EGTA, and $0.75 \mathrm{M}$ sucrose, $\mathrm{pH} \mathrm{7.0)}$ ) for $1 \mathrm{~min}$ before chemical fixation with buffer A containing $0.3 \mathrm{mM} \mathrm{m}$-maleimidobenzoyl$\mathrm{N}$-hydroxysuccinimide ester (Pierce, Rockford, IL) and $3.7 \%(\mathrm{~V} / \mathrm{v})$ formaldehyde (Pierce) for $30 \mathrm{~min}$. Fixed embryos were washed twice for $5 \mathrm{~min}$ in buffer $\mathrm{A}$ before incubation in buffer $\mathrm{A}$ containing $10 \mu \mathrm{M}$ fluorescein-phalloidin for $30 \mathrm{~min}$. Stained embryos were washed twice for 5 min in buffer A. Confocal microscopy of stained zygotes was performed using a Zeiss CLSM 410 (Thornwood, NY) equipped with an argon ion laser for illumination at $488 \mathrm{~nm}$. Fifteen optical sections were collected at $2-\mu \mathrm{m}$ intervals using a $510-$ to $540-\mathrm{nm}$ band pass filter to eliminate the majority of autofluorescence. The 15 optical sections were projected together, using $\mathrm{NIH}$-Image software. The final image was produced using a Phaser IISDX Dye Sublimation printer (Tektronix Inc., Wilsonville, OR).

\section{ACKNOWLEDGMENTS}

We thank Drs. Bernard Kloareg and Philippe Potin (Station Biologique, Roscoff, France) for providing us with alginate lyase and Dr. Kirk Apt (Carnegie Institution of Washington, Stanford, CA) for the FCpA cDNA clone. We are also grateful to Susan Whittield for assistance with photographic work and to members of the Quatrano laboratory, especially Dr. Crispin Taylor, for reading the manuscript. This research was supported by grants from the National Science Foundation (No. MCB 9318757) and the Office of Naval Research (No. N00014-93-1-0888) to R.S.Q. The NIH-Image soltware was written by Wayne Rasband at the U.S. National Institutes of Health and is available from the internet by anonymous FTP from zippy. nimh.nih.gov or on floppy disk from the National Technical information Service (Springfield, VA; part No. PB93-504868).

Received September 20, 1995; accepted December 15, 1995.

\section{REFERENCES}

Abe, S., You, W., and Davies, E. (1991). Protein bodies in corn endosperm are enclosed by and enmeshed in F-actin. Protoplasma $165,139-149$.

Allen, V.W., and Kropf, D.L. (1992). Nuclear rotation and lineage specification in Pelvetia embryos. Development 115, 873-883.

Apt, K.E., Clendennen, S.K., Powers, D.A., and Grossman, A.R. (1995). The gene family encoding the fucoxanthin chlorophyll proteins from the brown alga Macrocystis pyrifera. Mol. Gen. Genet. 246, 455-464

Beach, L.R., and Jeffery, W.R. (1990). Temporal and spatial expression of a cytoskeletal actin gene in the ascidian Styela clava. Dev. Genet. 11, 2-14.

Berger, F., Taylor, A., and Brownlee, C. (1994). Cell fate determination by the cell wall in early Fucus development. Science 263 , 1421-1423.

Bouget, F.Y., Gerttula, S., and Quatrano, R.S. (1995a). A new nonradioactive in situ hybridization protocol for Fucus (Phaeophyta) embryos. J. Phycol. 31, 1027-1030.

Bouget, F.Y., Gerttula, S., and Quatrano, R.S. (1995b). Spatial redistribution of poly $(A)^{+}$RNA during polarization of the Fucus zygote is dependent upon microfilaments. Dev. Biol. 171, 258-261.

Brawley, S.H., and Quatrano, R.S. (1979a). Sulfation of fucoidin in Fucus embryo. IV. Autoradiographic investigations of fucoidin sulfation and secretion during differentiation and the effect of cytochalasin treatments. Dev. Biol. 73, 193-205.

Brawley, S.H., and Quatrano, R.S. (1979b). Effect of microtubule inhibitors on pronuclear migration and embryogenesis in Fucus distichus (Phaeophyta). J. Phycol. 15, 266-272. 
Brawley, S.H., and Robinson, K.R. (1985). Cytochalasin treatment disrupts the endogenous currents associated with cell polarization in fucoid zygotes: Studies of the role of F-actin in embryogenesis. J. Cell Biol. 100, 1173-1184.

Brawley, S.H., Quatrano, R.S., and Wetherbee, R. (1977). Finestructural studies of the gametes and embryo of Fucus vesiculosus L. (Phaeophyta). III. Cytokinesis and the multicellular embryo. J. Cell Sci. 24, 275-294.

Burn, T.C., Vigoreaux, J.O., and Tobin, S.L. (1989). Alternative 5C actin transcripts are localized in different patterns during embryogenesis. Dev. Biol. 131, 345-355.

Cheng, H., and Bjernes, M. (1989). Asymmetric distribution of actin mRNA and cytoskeletal pattern generation in polarized epithelial cells. J. Mol. Biol. 210, 541-549.

Cox, K.H., Deleon, D.V., Angerer, L.M., and Angerer, R.C. (1984). Detection of mRNAs in sea urchin embryos by in situ hybridization using asymmetric RNA probes. Dev. Biol. 101, 485-502.

Cox, K.H., Angerer, L.M., Lee, J.J., Davidson, E.H., and Angerer, R.C. (1986). Cell lineage-specific programs of expression of multiple actin genes during sea urchin embryogenesis. J. Mol. Biol. 188, 159-172.

Cripe, L., Morris, E., and Fulton, A.B. (1993). Vimentin mRNA location changes during muscle development. Proc. Natl. Acad. Sci. USA 7, 2724-2728.

Davies, E., Fillingham, B.D., and Abe, S. (1996). The plant cytoskeleton. In Treatise on the Cytoskeleton, Vol. 4 (Greenwich, CT: JAl Press), in press.

Ephrusi, A., and Lehmann, R. (1992). Induction of germ cell formation by oskar. Nature 358, 387-392.

Fowler, J., and Quatrano, R.S. (1995). Cell polarity and fate determination in brown algal zygotes. In Seminars in Developmental Biology, Vol. 6, D. Kirk, ed (Cambridge, UK: Academic Press), pp. 347-358.

Fulton, A.B. (1993). Spatial organization of the synthesis of cytoskeletal proteins. J. Cell. Biochem. 52, 148-152.

Goodner, B., and Quatrano, R.S. (1993). Fucus embryogenesis: A model to study the establishment of polarity. Plant Cell 5, 1471-1481.

Goodner, B.W., Davis, J.D., and Quatrano, R.S. (1995). Sequence of actin cDNA from Fucus distichus. Plant Physiol. 107, 1007-1008.

Heath, I.B. (1990). The roles of actin in tip growth of fungi. Int. Rev. Cytol. 123, 95-127.

Hepler, P.K., and Bonsignore, C.L. (1990). Caffeine inhibition of cytokinesis: Ultrastructure of cell plate formation/degradation. Protoplasma 157, 182-192.

Hill, M.A., and Gunning, P. (1993). Beta and gamma actin mRNAs are differentially located within myoblasts. J. Cell Biol. 122, 825-832.

Horvitz, H.R., and Herskowitz, I. (1992). Mechanisms of asymmetric cell division: Two Bs or not two Bs, that is the question. Cell 68, 237-255.

Jeffery, W.R. (1989). Localized mRNA and the egg cytoskeleton. Int. Rev. Cytol. 119, 151-195.

Jeffery, W.R., Tomlinson, C.R., and Brodeur, R.D. (1983). Localization of actin messenger RNA during early ascidian development. Dev. Biol. 99, 408-417.

Jongens, T.A., Hay, B., Jan, L.Y., and Jan, Y.N. (1992). The germ cell-less product: A posteriorly localized component necessary for germ cell development in Drosophila. Cell 70, 569-584.
Kislauskis, E.H., and Singer, R.H. (1992). Determinants of mRNA Iocalization. Curr. Opin. Cell Biol. 4, 975-978.

Kislauskis, E.H., Zhu, X., and Singer, R.H. (1994). Sequences responsible for intracellular localization of $\beta$-actin messenger RNA also affect cell phenotype. J. Cell Biol. 127, 441-451.

Kropf, D.L. (1994). Cytoskeletal control of cell polarity in a plant zygote. Dev. Biol. 165, 361-371.

Kropt, D.L., Berge, S.K., and Quatrano, R.S. (1989a). Actin localization during Fucus embryogenesis. Plant Cell 1, 191-200.

Kropt, D.L., Hopkins, R., and Quatrano, R.S. (1989b). Protein synthesis and morphogenesis are not tightly linked during embryogenesis in Fucus. Dev. Biol. 134, 452-461.

Kropf, D.L., Maddock, A., and Gard, D.L. (1990). Microtubule distribution and function in Pelvetia early development. J. Cell Sci. 97, 545-552.

Kropf, D.L., Jordan, J.R., Allen, V.W., and Gibbon, B.C. (1992). Cellular polarity in Pelvetia zygotes: Studies of intracellular $\mathrm{pH}$ and division alignment. Curr. Top. Plant Biochem. Physiol. 11, 143-152.

Lawrence, J.B., and Singer, R.H. (1986). Intracellular localization of messenger RNAs for cytoskeletal proteins. Cell 45, 407-415.

Li, X., Franceschi, V.R., and Okita, T.W. (1993). Segregation of storage protein mRNAs on the rough endoplasmic reticulum membranes of rice endosperm cells. Cell 72, 869-879.

Luby Phelps, K. (1994). Physical properties of cytoplasm. Curr. Opin. Cell Biol. 6, 3-9.

Ludevid, D., Hofte, H., Himelbiau, E., and Chrispeels, M.J. (1992). The expression pattern of the tonoplast intrinsic protein g-TIP in Arabidopsis thaliana is correlated with cell enlargement. Plant Physiol 100, 1633-1639.

MacLean-Fletcher, S., and Pollard, T.D. (1980). Mechanism of action of cytochalasin B on actin. Cell 20, 329-341.

Masters, A.K., Shirras, A.D., and Hetherington, A.M. (1992). Maternal mRNA and early development in Fucus serratus. Plant J. 2, 619-622.

Mayer, U., Büttner, G., and Jürgens, G. (1993). Apical-basal pattern formation in the Arabidopsis embryo: Studies on the role of the gnom gene. Development 117, 149-162.

McIntosh, K., Pickett-Heaps, J.D., and Gunning, B.E.S. (1995) Cytokinesis in Spirogyra: Integration of cleavage and cell-plate formation. Int. J. Plant Sci. 156, 1-8.

Mineyuki, Y., and Palevitz, B.A. (1990). Relationship between preprophase band organization, F-actin and the division site in Allium. J. Cell Sci. 97, 283-295.

Poethig, S. (1989). Genetic mosaics and cell lineage analysis in plants. Trends Genet. 5, 273-277.

Pokrywka, N.J., and Stephenson, E.C. (1991). Microtubules mediate the localization of bicoid RNA during Drosophila oogenesis. Development 113, 55-66.

Quatrano, R.S. (1968). Rhizoid formation in Fucus zygotes: Dependence on protein and ribonucleic acid syntheses. Science 162, $468-470$

Quatrano, R.S. (1973). Separation of processes associated with differentiation of two celled Fucus embryos. Dev. Biol. 30, 209-213.

Quatrano, R.S. (1980). Gamete release, fertilization, and embryogenesis in the Fucales. In Handbook of Phycological Methods: Developmental and Cytological Methods, E. Gantt, ed (Cambridge, UK: Cambridge University Press), pp. 59-68. 
Raff, J.W., Whitfield, W.G.F., and Glover, D.M. (1990). Two distinct mechanisms localize cyclin B transcripts in syncitial Drosophila embryos. Development 110, 1249-1261.

Sambrook, J., F.ritsch, E.F., and Maniatis, T. (1989). Molecular Cloning: A Laboratory Manual, 2nd ed. (Cold Spring Harbor, NY: Cold Spring Harbor Laboratory Press).

Seydoux, G., and Fire, A. (1994). Soma-germline asymmetry in the distributions of embryonic RNAs in Caenorhabditis elegans. Development 120, 2823-2834.

Sonobe, S., and Shibaoka, H. (1989). Cortical fine actin filaments in higher plant cells visualized by rhodamine-phalloidin after pretreatment with $m$-maleimidobenzoyl $N$-hydroxysuccinimide. Protoplasma 148, 80-86.

St. Johnston, D. (1995). The intracellular localization of messenger RNAs. Cell 81, 161-170.

St. Johnston, D., and Nüsslein-Volhard, C. (1992). The origin of pattern and polarity in the Drosophila embryo. Cell 68, 201-219.

Sundell, C.L., and Singer, R.H. (1991). Requirement of microfilaments in sorting of actin messenger RNA. Science 253, 1275-1277.

Tautz, D., and Pfeifle, C. (1989). A non-radioactive in situ hybridization method for the localization of specific RNAs in Drosophila embryos reveals translational control of the segmentation gene hunchback. Chromosoma 98, 81-85.

Thomsen, G.H., and Melton, D.A. (1993). Processed Vg1 is an axial mesoderm inducer in Xenopus. Cell 74, 433-441.
Tobin, S.L., Cook, P.J., and Burn, T.C. (1990). Transcripts of individual Drosophila actin genes are differentially distributed during embryogenesis. Dev. Genet. 11, 15-26.

Torres-Ruiz, R.A., and Jürgens, G. (1994). Mutations in the fass gene uncouple pattern formation and morphogenesis in Arabidopsis development. Development 120, 2967-2978.

Torrey, J.G., and Galun, E. (1970). Apolar embryos of Fucus resulting from osmotic and chemical treatment. Am. J. Bot. 57, 111-119.

Traas, J.A., Doonan, J.H., Rawlins, D.J., Shaw, P.J., Watts, J., and Lloyd, C.W. (1987). An actin network is present in the cytoplasm throughout the cell cycle of carrot cells and associates with the dividing nucleus. J. Cell Biol. 105, 387-395.

Wang, C., Dickinson, L.K., and Lehmann, R. (1994). Genetics of nanos localization in Drosophila. Dev. Dyn. 199, 637-647.

Wharton, R.P., and Struhl, G. (1991). Regulatory elements mediate control of Drosophila body pattern by the posterior morphogen nanos. Cell 67, 955-967.

Wilhelm, J.E., and Vale, R.D. (1993). RNA on the move: The mRNA localization pathway. J. Cell Biol. 123, 269-274.

Yisraeli, J.K., Sokol, S., and Melton, D.A. (1990). A two-step model for the localization of maternal mRNA in Xenopus oocytes: Involvement of microtubules and microfilaments in the translocation and anchoring of $\mathrm{Vg} 1$ mRNA. Development 108, 289-298. 
Localization of Actin mRNA during the Establishment of Cell Polarity and Early Cell Divisions in Fucus Embryos.

F. Y. Bouget, S. Gerttula, S. L. Shaw and R. S. Quatrano Plant Cell 1996;8;189-201

DOI 10.1105/tpc.8.2.189

This information is current as of July 22, 2020

Permissions

eTOCs

CiteTrack Alerts

Subscription Information
https://www.copyright.com/ccc/openurl.do?sid=pd_hw1532298X\&issn=1532298X\&WT.mc_id=pd_hw1532298 $\mathrm{X}$

Sign up for eTOCs at:

http://www.plantcell.org/cgi/alerts/ctmain

Sign up for CiteTrack Alerts at:

http://www.plantcell.org/cgi/alerts/ctmain

Subscription Information for The Plant Cell and Plant Physiology is available at: http://www.aspb.org/publications/subscriptions.cfm 